Health care prioritization in ageing societies: Influence of age, education, health literacy and culture

B Mak[a*], J Woo [a,b], A Bowling [c], F Wong [b], PH Chau [a]

Faculty of Social Sciences, The University of Hong Kong [a]

Faculty of Medicine, The Chinese University of Hong Kong [b]

Health Services Research, University College of London [c]

*Address for Correspondence

Benise Mak

Faculty of Social Sciences

The University of Hong Kong

Room 104, Meng Wah Complex

Pokfulam Raod

Hong Kong

Tel: 2219-4273

Fax: 2986-4596

Email: benise@hku.hk

Running head: Health care prioritization in ageing societies

Word counts: 3990 


\section{Health care prioritization in ageing societies: Influence of age, education, health literacy and culture}

\section{ABSTRACT}

Objectives. To examine how Chinese people in Hong Kong view health care prioritization and to compare the findings with those from a United Kingdom survey.

Method. A cross-sectional opinion survey was conducted in Hong Kong and 1,512 participants were interviewed.

Results. Data show that the highest rankings were accorded to "treatment for children" and "high technology services.” Services for the elderly, whether in the community or in hospitals, and including end-of-life care, were ranked among the lowest. This view was also shared by healthcare professionals. Compared with the United Kingdom findings, there are stark contrasts in the low ranking of end-of-life care and the high ranking of high technology services among the Hong Kong population.

Conclusion. It is evident that most people would give priority to the young over the old in distributing a given amount of healthcare services. To meet the needs of ageing societies and to meet the needs of all users equitably, health care policy needs to acknowledge constraints and the needs for prioritization. Both the public and professionals should engage with policy makers in formulating a policy based on cost benefit considerations as well as overall societal view of prioritization that is not based on age alone.

Keywords: Elderly, Healthcare services, Priority setting 


\section{INTRODUCTION}

One consequence of aging populations is the accumulation of chronic disease and disability burden on health and social care systems in many developed countries. Although there is a declining trend in incidence of many chronic diseases such as cardiovascular diseases, the more rapid decline in mortality rate as well as the increasing prevalence with age result in an increase in the absolute numbers of people with chronic diseases and disability [1,2]. At the same time, rapid advances in more expensive medical technologies enabling better treatment, together with increasing health literacy of the population, result in an exponential increase in public expectation for health care in most countries [3]. Furthermore many countries have experienced an economic depression, which has worsened the discrepancy between the public's expectations and the services a community can afford to offer. As a result some form of rationing in health services seems inevitable $[4,5,6,7,8]$. As in other countries, the Hong Kong (HK) government healthcare budget is unable to keep up with the demand, so that the issue of prioritization in some areas of healthcare such as the criteria for receiving liver transplants has been raised [9]. Nevertheless, there has been little informed societal discussion or official acknowledgement relating to the consequence of demand exceeding government healthcare budget, resulting in prioritization occurring in an arbitrary manner.

Two levels of prioritization have been described: horizontal or vertical [10]. Horizontal prioritization is carried out at the political level, for example, allocation of resources between noninstitutional and hospital care or between different diseases groups. However, among the general public, the most commonly discussed level is vertical prioritization. This is concerned with how and how much care should be made for individuals.

The basis for prioritization has been discussed mainly in the use of age as a criterion. The growing number of older people is likely to place increasing demands on health services for access to effective 
health technology in cases in which this can enhance the quality, not just the quantity, of life [11]. There is some evidence that age has been used as a criterion in allocating health care. Previous studies have documented age discrimination in healthcare systems [11,12,13,14]. Studies have shown substandard treatment of older people with acute myocardial infarction and other forms of heart disease $[11,12]$ leading to premature deaths and unnecessary disability, as well as unavailability of breast screening for women aged 65 and over in Britain [15]. Care for older people with cancer is also poorer than that provided for younger patients $[13,16]$. It has been pointed out that medicine must be changed to serve an ageing society, in that health care is ill suited to perform well in a world with more elderly people, effectively resulting in 'arbitrary' discrimination. The special complex needs of elderly bear the brunt of rationing within the health service, this state of affairs being a poor reward for past contributions [17]. The media indirectly contributes to shaping negative ageist attitudes [18]. Nevertheless it has been pointed out that rationing of medical care by age may be inevitable, and the debate should be how government decides and whether the public should be consulted [19].

Callahan [20] stated that age is a legitimate basis for allocation of resources because it is a universal category and can easily be understood. He also stated that there should be an opportunity for every young person to become old and argued that to make that possible it is only fair to limit assistance to those who are already old. This view was supported by Daniels [21] who suggested that rationing by age is permissible under some conditions of scarcity. Williams [22,23] required greater discrimination against those who are older and asserted that everyone is entitled to a normal span of health and anyone who gets less than this has been cheated, while those who get more is living on borrowed time. Veatch [24] suggested guidelines for limiting care for people who are old and terminally ill and saw younger people as being worse off than older people because they have lived less of their lives [25]. On the other hand, several researchers [11,26,27,28,29,30,31] have argued against these theorists on the grounds of discrimination and ageism. As Giordano [29] stated that 
"there is no valid reason, either theoretical or empirical, to deny the elderly full membership to the human family (p. 90).”

It can be seen that policy decisions relating to rationing, or prioritization of health care depend on healthcare systems and financing as well as public opinion, and these vary between different societies. Factor that may affect prioritization in any given society include the percentage of elderly people, the level of education or health literacy, and cultural factors determining the status of older people. Previous studies have been carried out in Western cultures. Among Chinese, the status of older people may be higher [32]. There is little information regarding how Chinese people in a developed economy view health care prioritization. Furthermore there may be a discrepancy between societal view and the view from individual sufferers, between healthcare professionals and the people they serve. Currently in $\mathrm{HK}$, there is no official acknowledgement that there is limitation in health care resources or that there is a need for prioritization of services. To address these questions, we carried out a survey among Chinese people living in HK using a questionnaire that had been previously applied to the United Kingdom (UK) population [33], to obtain additional information on the influence of culture on health care prioritization.

\section{METHOD}

Design. A cross-sectional opinion survey was conducted in HK from January to November 2009. A quota sample of 1,512 participants was recruited from the HK non-institutional population aged 18 years and over. To examine the discrepancy between societal view and the view of elderly people and between healthcare professionals and the people they serve, healthcare professionals and the senior population were purposefully over-sampled to support subgroup analyses Hence, unlike Bowling [33] who did a population-representative sampling in the UK, a non-representative sample was recruited for this study. 
Questionnaire. The design of the questionnaire was based on the one used by Bowling [33]. There were three sections. In the first section (Prioritization Exercises), respondents were asked to prioritize 12 health services. In section two (Attitudes about Health Priorities), respondents were asked if they strongly disagreed to strongly agreed (on a five-point scale) with six statements about health priorities. In section three (Priority Setting), respondents were asked who they thought should set priorities and to select their preference from a list. They were also asked about how they themselves would allocate a health budget of HK\$20 million. Furthermore, respondents were asked if they agree the general public's opinions, like this one, should be used in the planning of health services. Finally, sociodemographic data were collected. Details of the questionnaire were shown in Appendix 1. Measures on the reliability and validity of the questionnaire have not been estimated, as the major objective of this study was to examine how people prioritise healthcare resources and it was not intended to develop a scale of age disparity.

Procedure. Hardcopies of the questionnaire were distributed to the staff of selected hospitals, visitors to selected hospitals and universities, the staff and members of elderly centers, as well as the older visitors to the public parks in all 18 districts of HK. Respondents were given sufficient time to complete and return the questionnaires to the research assistants at the site of recruitment. For subjects with lower education level, in particular the older respondents, the trained research assistants read out the questions to them and helped complete the questionnaires. If the respondents had any queries, the research assistants would also provide explanations based on some standard answers so that misunderstanding of the questions was minimized. Web-based questionnaires were also sent to undergraduate students of selected universities and the staff of selected universities and large corporations through bulk email. Informed consent was obtained from the participants, and the study 
was approved by the ethical committees of The University of Hong Kong and The Chinese University of Hong Kong.

Statistical Analysis. For each respondent, a score of 1 was assigned to the health service being given the first priority, 2 to the second and so on. The mean of the priority ratings of the sample were calculated for each of the twelve health services. These services were then sorted in ascending order of mean priority rating, with the smallest value indicating the highest priority.

In subgroup analysis, the priority ratings $(1,2, \ldots 12)$ were divided into four groups of priority (very high, high, low, very low), which was used as the dependent variable of ordinal regression. For questions involving degree of agreement, “strongly agree” and “agree” were grouped as “agree”, which was used as the dependent variable of binary logistic regression. Responses to questions with only two options were also analyzed by binary logistic regression. To control for confounding, gender, age, education level, economic and professional status as well as health status were included in the models as independent variables. SPSS version 17.0 was used for statistical analysis and a significance level of 0.05 was used.

\section{RESULTS}

Of the 1,512 respondents, about $45 \%$ were $18-49$ years of age, $18 \%$ were $50-64$ years and $37 \%$ were 65 years and over. This distribution was different from the HK population: 59\% were 20-49 years of age, $25 \%$ were $50-64$ years of age, and $16 \%$ were 65 years and over. This was mainly due to the oversampling of the older population in order to investigate the discrepancy between societal view and the view of elderly people. The sociodemographic characteristics of the sample were shown in Table 1.

\section{Prioritization Exercises}


Table 2 shows the frequency distributions and the mean priority rankings for the 12 services and treatments. The table shows that the highest priority (rank 1) was accorded to "treatment for children with life threatening illnesses," the next highest priority (rank 2) was accorded to "high technology surgery, organ transplants and procedures which treat life threatening conditions." "Preventive screening services and immunizations” were ranked next highest (3) which was followed by "surgery, such as hip replacement, to help people carry out everyday tasks" (4). "Health promotion/education services to help people lead healthy lives" was given a middle ranking (5) as were "psychiatric services for people with mental illness" (6) and "district nursing and community services/care at home” (7); "long stay hospital care for elderly people” was given a middle to low ranking (8). The lowest priorities were assigned to "treatment for people aged 75 and over with life threatening illness" (rank 9), “special care and pain relief for people who are dying” (10), “intensive care for premature babies who weigh less than 680 g with only a slight chance of survival" (11) and "treatment for infertility” (12).

\section{Attitudes about Health Priorities}

Table 3 shows the respondents’ attitudes about health priorities. Most respondents (58\%) agreed or strongly agreed that "high cost technology should be available to all regardless of age," which somewhat contradicts the low ranking (9) of "treatments for elderly people” (Table 2), illustrating the complexity of prioritization by age group. However, it appears to be consistent with the high ranking (2) of "high technology surgery." Being consistent with the high ranking (1) of "treatment for children” and the low ranking (9) of “treatment for elderly people” in the priority ranking exercise (Table 2), about $44 \%$ of respondents agreed or strongly agreed that "if resources are to be rationed then higher priority should be given to treating the young rather than elderly people.” However, in contrast to the low priority ranking (10) of “end-of-life care” (Table 3), most respondents (69\%) 
agreed or strongly agreed that “the patient's quality of life should be considered in determining whether or not to use lifesaving treatment/technology.”

Table 3 also shows that half of the respondents (55\%) agreed or strongly agreed that "people who contribute to their own illness should have lower priority for health care." About half of the respondents (48\%) agreed or strongly agreed that "the responsibility for rationing health care should rest with doctors,” echoing a similar direct question about who should set priorities (as described below). Inconsistent with this, respondents were divided on whether "the government should issue guidelines to doctors about rationing lifesaving treatments,” with $46 \%$ agreed or strongly agreed and 38\% disagreed or strongly disagreed.

\section{Priority Setting}

Respondents were asked to rank who should set priorities, 43\% ranked “doctors at local level” the first priority, 21\% ranked “the public,” 19\% ranked “Hospital Authority,” 11\% ranked "hospital managers,” and 6\% ranked "politicians and the government.” In addition, most respondents (77\%) agreed that "surveys of the general public's opinions, like this one, should be used in the planning of health service,” $10 \%$ disagreed with this, and 13\% said that they did not know.

They were also asked how they themselves would allocate a spare HK\$20 million health budget. Seventy one percent of the respondents selected "a health screening and education programme which could prevent a large number of people needing lifesaving operations in the future” and 29\% selected “10 extra immediate lifesaving operations this year.”

\section{Subgroup Analysis}

There were a few associations between health service priorities and sociodemographic characteristics (Table 4). For example, younger people (age groups: 18-49 and/or 50-64) tended to give a lower priority to health services for elderly people (such as, "community services,” "long stay hospital care,” 
and "treatment for elderly people”) than older people aged 65 and over. However, for services concerning children (such as, “treatment for children” and "intensive care for premature babies”) and services involving surgery (such as, "high technology surgery” and "hip surgery”), younger people (age groups: 18-49 and/or 50-64) gave a higher ranking than older people aged 65 and over.

Moreover, people with tertiary education set a higher priority to "health promotion" and “preventive screening” but a lower ranking to "hip surgery" and "infertility treatment” than those without tertiary education.

Professionals gave a higher ranking to “community services” but a lower priority to "treatment for elderly people” than non-professionals. Healthcare professionals set a lower priority to “intensive care for premature babies” but a higher priority to "health promotion” than non-healthcare workers.

There were also a few associations between attitudes to health priorities and sociodemographic characteristics (Table 5). Compared with older people (65 and over), younger people (age groups: 1849 and/or 50-64) were less likely to agree that "people who contribute to their own illness should have lower priority for health care," "if resources are to be rationed then higher priority should be given to the young,” and “patient's QOL should be considered in using lifesaving treatment.” In allocating a spare HK\$20 million health budget, more older people (aged 65 and over) preferred “10 extra lifesaving operations” to "a health screening and education programme” than younger people (aged 18-49 and 50-64).

Furthermore, in comparison to people with tertiary education, those without tertiary education tended to agree that "high cost technology should be available to all," "people who contribute to their own illness should have lower priority," and "the responsibility for rationing health care should rest with doctors." They were also more likely to choose “10 extra lifesaving operations” in allocating a spare HK\$20 million health budget. On the other hand, people with tertiary education tended to agree that “patient's QOL should be considered in using lifesaving treatment.” This finding suggests that 
raising health literacy particularly among those with lower education levels may reduce the over reliance on high cost technology and operations, and on doctors only, for health management.

Healthcare professionals, in contrast to non-healthcare workers, were less likely to agree that "high cost technology should be available to all," and "the responsibility for rationing health care should rest with doctors." Nonetheless, they tended to agree that "if resources are to be rationed then higher priority should be given to the young,” and “patient's QOL should be considered in using lifesaving treatment.” In addition, healthcare professionals were less likely to agree that "surveys of the general public’s opinions, like this one, should be used in the planning of health service.”

\section{International Comparison}

To compare the present findings with those of a UK survey reported by Bowling [33], the HK sample is weighted in accordance to the UK sample’s age composition. Results were shown in Table 6 and 7.

Table 6 indicates that respondents in HK and those in UK prioritised the 12 health services more or less the same way except that those in the HK sample set a lower priority to "end-of-life care” (rank 10) than people in the UK sample (rank 2). HK people also set a lower priority to "intensive care for premature babies” (rank 11) than UK people (rank 9). However, HK people gave a higher priority (rank 2) to "high technology surgery" than UK people (rank 7). They also gave a higher priority (rank 5) to "health promotion” than those in UK (rank 8). In prioritizing "treatment for elderly people,” HK people set a higher priority (rank 9) than UK people (rank 12). Similarly, "long stay hospital care” was given a higher priority among HK people (rank 8) than that among UK people (rank 10).

Regarding the comparison between HK and UK people's attitudes to health priorities, Table 7 shows that substantially less HK people agreed that "high cost technology should be available to all" (56\% vs. 80\%), “the responsibility for rationing health care should rest with doctors” (47\% vs. $75 \%$ ), whereas more people in the HK sample agreed that "the government should issue guidelines to doctors" (46\% vs. 14\%). In contrast to the striking difference in ranking of "end-of-life care” (Table 
7), the percentages of agreeing “patient’s QOL should be considered in using lifesaving treatment” are similar between HK and UK people (69\% vs. 74\%).

\section{DISCUSSION}

This is the first study exploring the views of the public as well as health and social care professionals on how healthcare resources should be prioritized among a Chinese population living in a developed economy. The findings show that services for the elderly, whether in the community or in hospitals, and including end-of-life care, were ranked among the lowest. Older people who may be existing users or in need of these services tend to rate these services higher than younger age groups. It appears that there is a general view that older people have lower priority than younger people, yet those who currently stand to benefit from these services gave a higher priority, suggesting the existence of factors that may predispose to age disparities in the provision of these services. Furthermore, the findings may suggest that those who responded did so from their current perspective of needs, rather than from societal needs using an altruistic perspective. However, one may not draw the conclusion that Chinese society is necessarily self-centered, since factors such as lack of discussion and existence of elder care policies, under-developed elder care services, and predominantly negative media portrayal of elder issues may have major roles in contributing to this response. Notably views of those with higher education were not different from the general public in regards of the elderly services. While healthcare professionals gave lower priority to long stay hospital care for elderly people and treatment for people aged 75 and over, they gave higher priority to nursing and long term care, as compared to other economic and professional groups.

Other surveys of public opinion have similar results in that most people would give priority to the young over the old in distributing a given amount of health care benefit [33,34]; an attitude also shared 
by healthcare professionals $[34,35,36]$. Several studies have indicated that age is a criterion that people generally use to prioritise healthcare services and physicians use even more often [11,34,35,36]. For example, Myllykangas and others [35] found that physicians were less willing to prioritise older people than were nurses, politicians and the general public. Physicians were less willing than other groups to refer older patients for elective surgery [34], and ageism also exists in access to cardiology services [11].

The stark contrast in the low ranking of end-of-life care compared with the UK findings, where it is ranked second, may represent a cultural difference between Chinese and Caucasians. In general among Chinese, death is still a taboo subject and even healthcare professionals may not be comfortable in discussing it openly. As a result there may be much misconception about the importance of these services in achieving a measure of quality of life at the end, or placing importance on the quality of dying. This finding is somewhat unexpected given the results of a previous survey where over 95\% of the public would like to have an input regarding end-of-life care [37], and about $60 \%$ would like to discuss the issue of euthanasia [38]. One possible explanation is that while palliative care for cancer patients is well developed, services for those dying of chronic diseases have not been developed in a comparable way. Surprisingly, this study showed that around 70\% of HK and UK people agreed that patient's quality of life should be considered in determining whether or not to use lifesaving treatment or technology. One possible explanation is that while $\mathrm{HK}$ people are interested in end-of-life care, they do not see the importance of it when priority has to be given.

Another striking contrast to the UK finding is the much higher ranking accorded to high technology services among the HK population, particularly among the younger age groups. This may reflect the perception that technology is effective in dealing with many commonly encountered diseases accompanying ageing. Again the media may have contributed to this collective thinking, 
since discoveries that are reported by media, in particular local media, tend to be sensational and promote the view that many problems can be solved by technological advances. Given limited budgets and the expense of high technology services, disparities with respect to age may well occur. A systematic audit with respect to the extent of prioritization using age in the public health care sector may be indicated if inequalities in healthcare are to be reduced, similar to the initiative to reduce health inequalities due to socioeconomic factors advocated by the World Health Organization [39].

With respect to preventive services, those with higher education level and professionals accorded these higher rankings. Since preventive services are of key importance to public healthcare systems, the findings suggest that more public education should be carried out to show the importance of prevention, in raising the general health literacy of the population. Comparison with UK findings suggests that the level of health literacy may be lower. It is also interesting that the Chinese population appears to take a slightly more judgmental view about people who have chronic diseases as a result of their lifestyle, compared with the survey in the UK, in that a lower priority should be given to spending public money on treating these diseases. However issues such as whether those who continue to smoke will have lower priority in receiving coronary revascularization procedures have not been raised.

The findings of this survey may be useful for health policy planners. A majority of those surveyed thought that such surveys should be used in the planning of health services. However, unlike other studies where the general public placed confidence in physicians but not in politicians as decision makers in setting priority $[33,40,41]$, there is no clear pattern of opinions regarding whether it should be the public, the government, managers or doctors who set priorities. In order to avoid any inappropriate rationing of healthcare based on low health literacy regarding age-related issues and the perverse incentives of project based funding in health and social care sectors, the reality of financial 
constraints in the public healthcare system should be openly acknowledged; the health needs of ageing populations and what services could be provided listed comprehensively; the cost benefit of treatment involving new technology articulated; and then a consensus reached regarding prioritization that would result in an explicit policy being incorporated into the current healthcare system. Such a direction may also encourage the development of service models that involve co-payment or selffinancing, thereby countering the view the health is the responsibility of the government alone, and at the same time promoting public participation in shaping services for their own ageing.

There are limitations in this study. In examining the influence of culture, we did not carry out an exhaustive primary comparison with many countries, but used the findings of a previous UK survey. This allowed a more in depth comparison using a similar questionnaire. The UK survey was not designed to specifically address the issue of prioritization of services based on age. It is recognized that it is not easy to distinguish between age discrimination per se and prioritization based on other cirtieria that are associated with age. For example denying thrombolytic treatment for acute stroke to a patient who is 85 years old is justified because of the high risk of cerebral haemorrhage from the treatment. Denying treatment based on fewer expected quality of life-adjusted years may also be considered a valid reason for denying treatment to some elderly patients. In the questionnaire, age was not specifically referred to. Therefore the role of age as a factor for prioritization for services may not be clearly ascertained from the responses, since it is uncertain how a particular question was understood by the respondents. Although the sample was weighted for age between this survey population and that in the UK survey, the sample was not matched for education and employment. The study purposely over-sampled older age groups as well healthcare professionals in order to elicit subgroup differences. Furthermore, the UK survey was carried out over ten years ago, and the responses may have changed. Inherent to this type of survey, there is bias of non-responders. Completion of the questionnaire requires a higher level of education and health literacy; frail or 
institutionalized elderly would have been excluded. Furthermore, although the purposeful sampling included a category of policy makers, of all the questionnaires sent to government legislators, there was only one response. Nevertheless, in spite of all these differences, there are striking similarities between the rankings of the UK and HK population, with the exception of two items, the low ranking for end of life care and high ranking of technology in the HK population, that have been discussed above.

Moreover, it is possible that there were mode effects in adopting different data collection methods in a study $[42,43,44]$, like the paper and web-based self-administrated questionnaires and face-to-face interviews used in this study. To minimize the mode effects, we have taken some measures. First, the present study investigated how people prioritise healthcare services. We noted that the concept of health prioritization, unlike some socially undesirable issues, was quite neutral in HK. Second, the format of the web-based questionnaire was the same as the paper form. Third, for respondents with lower education level, the trained research assistants would read out the questions to them and helped clarify the questions when needed.

In conclusion, to meet the needs of ageing societies and to meet the needs of all users equitably, health care policy needs to acknowledge constraints and the needs for prioritization. Both the public as well as professionals should engage with policy makers in formulating a policy based on cost benefit considerations as well as overall societal view of prioritization that is not based on age alone. The findings of this study may be of relevance to East Asian countries that are ageing rapidly where financing of health and social care are becoming major issues, such as mainland China, Taiwan, Singapore, Japan, Korea, and Malaysia [45]. 


\section{REFERENCES}

[1] Crimmins EM. Trends in the health of the elderly. Annual Review of Public Health 2004;25:7998.

[2] Khaw KT. How many, how old, how soon? British Medical Journal 1999;319:1350-2.

[3] Cochrane M, Ham C, Heginbotham C, Smith R. Rationing: At the cutting edge. British Medical Journal 1991;303:1039-42.

[4] Callahan D. Rationing medical progress. The way to affordable medical care. New England Journal of Medicine 1990;322:1810-3.

[5] Eddy DM. Health system reform. Will controlling costs require rationing services? Journal of the American Medical Association 1994;272:324-7.

[6] Ham C. Priority setting in health care: Learning from international experience. Health Policy 1997; 42:49-66.

[7] Murphy DJ, Povar GJ, Pawlson LG. Setting limits in clinical medicine. Archives of Internal Medicine 1994;154:505-12.

[8] Ryynänen OP, Myllykangas M, Kinnunen J, Takala J. Attitudes to health care prioritisation methods and criteria among nurses, doctors, politicians and the general public. Social Science \& Medicine 1999;49:529-39.

[9] Chan HM, Cheung GM, Yip AK. Selection criteria for recipients of scarce donor livers: A public opinion survey in Hong Kong. Hong Kong Medical Journal 2006;12: 40-6.

[10] Werntoft E, Edberg AK. Decision makers' experiences of prioritisation and views about how to finance healthcare costs. Health Policy 2009;92:259-67.

[11] Bowling A. Ageism in cardiology. British Medical Journal 1999;319:1353-5.

[12] Bramstedt KA. Aortic valve replacement in the elderly: Frequently indicated yet frequently denied. Gerontology 2003;49:46-49. 
[13] Protière C, Viens P, Rousseau F, Moatti JP. Prescribers' attitudes toward elderly breast cancer patients. Discrimination or empathy? Critical Reviews in Oncology/Hematology in press.

[14] Rudd AG, Hoffman A, Down C, Pearson M, Lowe D. Access to stroke care in England, Wales and Northern Ireland: The effect of age, gender and weekend admission. Age and Ageing 2007; 36:247-55.

[15] Sutton GC. Will you still need me, will you still screen me, when I'm past 64? British Medical Journal 1997;315:1032-3.

[16] Jagsi R, DeLaney TF, Donelan K, Tarbell NJ. Real-time rationing of scarce resources: The Northeast Proton Therapy Center experience. Journal of Clinical Oncology 200;22:2246-50.

[17] Tonks A. Medicine must change to serve an ageing society. British Medical Journal 1999;319:1450-1.

[18] Martin R, Williams C, O’Neill D. Retrospective analysis of attitudes to ageing in the Economist: apocalyptic demography for opinion formers? British Medical Journal 2009;339:b4914.

[19] Allan R. Rationing of medial care by age. Clinical Medicine 2006;6:329.

[20] Callahan D. Setting limits: medical goals in an aging society. Washington, DC: Georgetown University Press; 1995.

[21] Daniels N. Just healthcare. Cambridge, UK: Cambridge University Press; 1985.

[22] Williams A. Intergenerational Equity: An Exploration of the 'Fair Innings' Argument. Health Economics 1997;6:117-32.

[23] Williams A. The rationing debate: Rationing health care by age: The case for. British Medical Journal 1997;314:820.

[24] Veatch RM. Justice and the Economics of Terminal Illness. The Hasting Center Report 1988;18:34-40.

[25] Persad G, Wertheimer A, Emanuel EJ. Principles for allocation of scarce medical interventions. The Lancet 2009;373:423 - 31. 
[26] Bell N. What setting limits may mean: A feminist critique of Daniel Callahan's Setting Limits. Hypatia 1989;4:169-78.

[27] Cohen-Almagor R. A critique of Callahan's utilitarian approach to resource allocation in health care. Issues in Law \& Medicine 2002;17:247-61.

[28] Evans JG. The rationing debate: Rationing health care by age: The case against. British Medical Journal 1997;314:822.

[29] Giordano S. Respect for equality and the treatment of the elderly: Declarations of human rights and age-based rationing. Cambridge Quarterly of Healthcare Ethics 2005;14:83-92.

[30] Purviance S. Age rationing, the virtues, and wanting more life. Journal of Medical Humanities 1993;14:149-65.

[31] Rivlin MM. Why the fair innings argument is not persuasive. BMC Medical Ethics 2000;1:E1.

[32] Yang CK. The Chinese family in the communist revolution. Cambridge, MA: Havard University Press; 1959.

[33] Bowling A. Health care rationing: the public's debate. British Medical Journal 1996;312:670-4.

[34] Ryynänen OP, Myllykangas M, Kinnunen J, Takala J. Doctors' willingness to refer elderly patients for elective surgery. Family Practice 1997;14:216-9.

[35] Myllykangas M, Ryynanen OP, Lammintakanen J, Isomaki VP, Kinnunen J, Halonen, P. Clinical management and prioritization criteria: Finnish experiences. Journal of Health Organization and Management 2003;17:338-48.

[36] Valtonen H. Patient characteristics and fairness. European Journal of Health Economics 2009;10;179-86.

[37] Chau PH, Mak B, Choy SY, Chan KC, Cheung SH, Woo J. Raising health literacy and promoting empowerment to meet the challenges of ageing in Hong Kong Special Administrative Region. Educational Gerontology 2101;36:12-25. 
[38] Fok SY, Chong A. Euthanasia and old age: the case of Hong Kong. Hallym International Journal of Aging 2003;5:41-53.

[39] Marmot M. Social determinants of health inequalities. The Lancet 2005;365:1099-104.

[40] Werntoft E, Edberg AK, Rooke I, Hermeren G, Elmstahl S, Hallberg IR. Older people's views of prioritization in health care: The applicability of an interview study. Journal of Clinical Nursing 2005;14:64-74.

[41] Werntoft E, Hallberg IR, Edberg AK. Older people's reasoning about age-related prioritization in health care. Nursing Ethics 2007;14:399-412.

[42] Aquilino WS. Interview mode effects in surveys of drug and alcohol use: A field experiment. Public Opinion Quarterly 1994;58:210-240.

[43] Dillman DA, Christian LM. Survey mode as a source of instability in responses across surveys. Field Methods 2005;17:30-52.

[44] Kreuter F, Presser S, Tourangeau R. Social desirability bias in CATI, IVR, and web surveys: The effects of mode and question sensitivity. Public Opinion Quarterly;72:847-865.

[45] Fu TH, Hughes R, editors. Ageing in East Asia challenges and policies for the twenty-first century. London: Routledge; 2009. 


\section{Appendix 1: Questionnaire}

\section{Section I: Priority rating of health services}

Please arrange the below 12 twelve health services, in the order from highest priority to lowest priority by filling in the boxes with the corresponding codes.

1. District nursing and community services/care at home

2. Treatment for infertility

3. Psychiatric services for people with mental illness

4. Surgery, such as hip replacement, to help people carry out everyday tasks

5. Treatments for children with life threatening illnesses

6. Special care and pain relief for people who are dying

7. Preventive screening services and immunizations

8. Long stay hospital care for elderly people

9. Treatment for people aged 75 and over with life threatening illness

10. High technology surgery, organ transplants and procedures which treat life threatening conditions

11. Health promotion/education services to help people lead healthy lives

12. Intensive care for premature babies who weigh less than $680 \mathrm{~g}$ with only a slight chance of survival

\section{Section II: Attitude about health priorities}

Please cross " $X$ " with the appropriate boxes to indicate the extent of your agreement or disagreement to the following six statements.

1. High cost technology (for example, transplantation and kidney machines) should be available to all regardless of age.

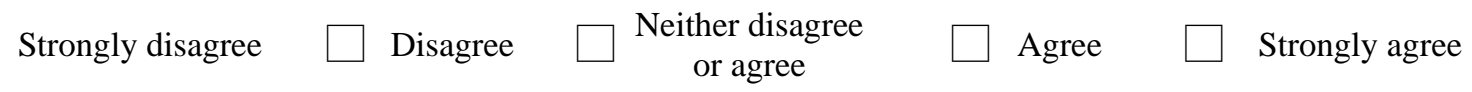

2. People who contribute to their own illness - for example, through smoking, obesity, or excessive drinking - should have lower priority for their health care than others.
Strongly disagree
Disagree
Neither disagree
or agree
Agree
Strongly agree

3. The responsibility to ration health care spending should rest with the doctor rather than a hospital manager, health authority, politician, or government minister.
Strongly disagree
Disagree
Neither disagree
or agree
Agree
Strongly agree

4. The government should issue guidelines to doctors about when not to use lifesaving medical treatment/technology. 
$\square$ Strongly disagree $\square$ Disagree $\quad \square \begin{gathered}\text { Neither disagree } \\ \text { or agree }\end{gathered}$ Agree $\quad \square$ Strongly agree

5. If resources must be rationed, higher priority should be given to treating the young than the elderly.

$\square$ Strongly disagree $\square$ Disagree $\quad \square \begin{gathered}\text { Neither disagree } \\ \text { or agree }\end{gathered}$ Agree $\quad \square$ Strongly agree

6. The patient's quality of life should be considered in determining whether or not to use lifesaving treatment/technology.

$\square$ Strongly disagree $\square$ Disagree $\quad \square \begin{gathered}\text { Neither disagree } \\ \text { or agree }\end{gathered}$ Agree $\quad \square$ Strongly agree

\section{Section III}

If health services rationing is inevitable, Please arrange from who should have most say in setting priorities for health services. (1 - Should have the most say, 5 - Should have the least say)

Doctors at local level

Hospital managers

The public

Hospital Authority

Politicians and the government

If you were in charge of the Hospital Authority with HK\$20 million left to allocate for your health budgets, which of the following would you choose to do? (Please cross " $X$ " for the appropriate.)

$\square$ A health screening and education programme which could prevent a large number of people needing lifesaving operations in the future (for example, screening for cancers)

$\square 10$ extra immediate lifesaving operations this year (for example, heart bypass or organ transplants)

Do you agree surveys of the general public's opinions, like this one, should be used in the planning of health services? (Please cross “ $X$ ” for the appropriate.)

Agree

Disagree

I don't know 
Please fill in the form below. (Please cross " $\mathrm{X}$ ” for the appropriate.)

1. Age

2. Sex $\square$ Male $\square$ Female

3. Marital status
Single
Married or cohabiting
Divorced / separated
Widowed

\section{District of residence :}

Central \& Western

$\checkmark$ Sham Shui Po

$\square$ Eastern

$\square$ Southern

$\square$ Wan Chai

$\square$ Yau Tsim Mong

$\square$ Sha Tin

$\square$ Wong Tai Sin

$\square$ Kwun Tong

$\square$ Sai Kung

$\square$ Kowloon City

$\square$ Yuen Long

$\square$ Tai Po

$\square$ Tsuen Wan

$\square$ Kwai Tsing

$\square$ Tuen Mun

Islands

5. Housing tenure :
$\square$ Owner-occupier
Tenant
$\square$ Provided by employer
$\square$ Rent free

$\square$ Others, please specify:

6. Educational level :

$\square$ Informal education

$\square$ Lower secondary

$\square$ Tertiary (non-degree)

$\square$ No schooling / Pre-
school
$\square$ Upper secondary
$\square$ Degree

$\square$ Primary

$\square$ Matriculation

$\square$ Postgraduate

7. Economic activity :

\begin{tabular}{|c|c|c|c|}
\hline Retired & $\neg$ Home-makers & $\begin{array}{l}\square \text { Managers and } \\
\text { administrators }\end{array}$ & $\square$ Professionals \\
\hline Associate professionals & Clerks & $\begin{array}{l}\square \text { Service workers } \\
\text { and shop sales } \\
\text { workers }\end{array}$ & $\begin{array}{c}\square \text { Craft and related } \\
\text { workers }\end{array}$ \\
\hline $\begin{array}{l}\text { Plant and machine } \\
\text { operators and assemblers }\end{array}$ & $\begin{array}{l}\text { Elementary } \\
\text { occupations }\end{array}$ & $\square$ Unemployed & $\begin{array}{l}\square \text { Others, please specify } \\
\quad:\end{array}$ \\
\hline $\begin{array}{l}\text { Selt rated state of health } \\
\text { Excellent } \quad \square \text { Very good }\end{array}$ & Good & Very & \\
\hline
\end{tabular}

9. Health status

$\square$ Longstanding illness $\square$ Disability or infirmity $\square$ Longstanding illness \& infirmity $\square$ None 
Health care prioritization in ageing societies

10 Ethnic group

$\square$ Chinese $\square$ Non-Chinese 


\begin{tabular}{|c|c|c|}
\hline Characte & & Percentage\% Frequency \\
\hline \multicolumn{3}{|l|}{ Age: } \\
\hline & $18-49$ & $45.4(687)$ \\
\hline & $50-64$ & $18.0(272)$ \\
\hline & $\geq 65$ & 36.6 (553) \\
\hline \multicolumn{3}{|l|}{ Sex: } \\
\hline & Male & 38.5 (582) \\
\hline & Female & 61.5 (930) \\
\hline \multicolumn{3}{|c|}{ Marital status: } \\
\hline & Married & $58.7(887)$ \\
\hline & Single & 31.3 (474) \\
\hline & Widowed, divorced or separated & $10.0(151)$ \\
\hline \multicolumn{3}{|c|}{ Ethnic group: } \\
\hline & Chinese & $98.7(1492)$ \\
\hline & Non-Chinese & $1.3(20)$ \\
\hline \multicolumn{3}{|c|}{ Housing tenure: } \\
\hline & Owner-occupier & 59.9 (905) \\
\hline & Tenant & 34.3 (519) \\
\hline & Provided by employer & $1.0(15)$ \\
\hline & Rent free & $3.1(47)$ \\
\hline & Others & $1.7(26)$ \\
\hline \multicolumn{3}{|c|}{ Economic activity: } \\
\hline & Working (full or part-time) & $45.1(682)$ \\
\hline & Unemployed or inactive & 54.9 (830) \\
\hline \multicolumn{3}{|c|}{ Economic activity (Position): } \\
\hline & Retired & 42.1 (636) \\
\hline & Home-makers & $3.2(49)$ \\
\hline & Managers and administrators & $4.5(68)$ \\
\hline & Professionals & 23.1 (349) \\
\hline & Associate professionals & $3.9(59)$ \\
\hline & Clerks & 7.6 (115) \\
\hline & Service workers and shop sales workers & $2.3(35)$ \\
\hline & Craft and related workers & $0.6(9)$ \\
\hline & Plant and machine operators and assemblers & $0.5(7)$ \\
\hline & Elementary occupations & $1.3(20)$ \\
\hline & Unemployed & $2.6(39)$ \\
\hline & Others & $2.0(30)$ \\
\hline & Student & $6.3(96)$ \\
\hline \multicolumn{3}{|c|}{ Health Status: } \\
\hline & Longstanding illness & $31.1(470)$ \\
\hline & Disability or infirmity & $0.7(11)$ \\
\hline & Longstanding illness \& infirmity & $1.1(17)$ \\
\hline & None & $67.1(1014)$ \\
\hline & $\begin{array}{l}\text { Regroup } \\
\text { None reported }\end{array}$ & 67.1 (1014) \\
\hline & Reported longstanding illness, disability or both & 32.9 (498) \\
\hline \multicolumn{3}{|c|}{ Self-rated state of health: } \\
\hline & Excellent & $5.8(88)$ \\
\hline & Very good & $25.6(387)$ \\
\hline & Good & 32.1 (485) \\
\hline & Poor & $32.0(484)$ \\
\hline & Very poor & $4.5(68)$ \\
\hline \multicolumn{3}{|c|}{ Educational Level: } \\
\hline & Informal education & $2.4(37)$ \\
\hline & No schooling or Pre-primary & $8.1(122)$ \\
\hline & Primary & $18.0(272)$ \\
\hline & Lower secondary & $11.7(177)$ \\
\hline & Upper secondary & $14.2(214)$ \\
\hline & Matriculation & $2.8(43)$ \\
\hline & Tertiary (non-degree) & 7.9 (119) \\
\hline & Degree & $21.0(318)$ \\
\hline & Postgraduate & $13.9(210)$ \\
\hline Total & & 1512 \\
\hline
\end{tabular}




\section{Table 2 - Priority rating of health services. Figures are percentages (numbers)}

\begin{tabular}{|c|c|c|c|c|c|c|c|c|c|c|c|c|c|c|c|c|c|c|c|c|c|c|c|}
\hline \multirow[b]{2}{*}{ Priority } & \multicolumn{23}{|c|}{ Priority rank } \\
\hline & & 1 & & 2 & & 3 & & 4 & & 5 & 6 & & 7 & & 8 & & 9 & 10 & 11 & 12 & $\mathrm{~N}$ & Mean & $\begin{array}{c}\text { Mean p } \\
\text { rank }\end{array}$ \\
\hline $\begin{array}{l}\text { Treatment for children with life } \\
\text { threatening illnesses }\end{array}$ & 30.22 & $(457)$ & 15.15 & $(229)$ & 12.76 & (193) & 9.59 & (145) & 7.80 & (118) & 6.08 (92) & 5.49 & $(83)$ & 5.16 & (78) & 2.91 & $(44)$ & 2.84 (43) & 1.39 (21) & $0.60(9)$ & 1512 & 3.69 & 1 \\
\hline $\begin{array}{l}\text { High technology surgery, organ } \\
\text { transplants and procedures } \\
\text { which treat life threatening } \\
\text { conditions } \\
\end{array}$ & 9.72 & $(147)$ & 15.01 & (227) & 12.96 & (196) & 11.64 & (176) & 9.19 & (139) & 8.53 (129) & 7.54 & (114) & 7.54 & (114) & 6.15 & $(93)$ & 6.35 (96) & 3.90 (59) & $1.46(22)$ & 1512 & 5.15 & 2 \\
\hline $\begin{array}{l}\text { Preventive screening services } \\
\text { and immunisations }\end{array}$ & 9.99 & (151) & 13.89 & $(210)$ & 10.05 & (152) & 7.67 & (116) & 7.67 & (116) & 8.20 (124) & 7.94 & $(120)$ & 8.99 & (136) & 9.33 & $(141)$ & 8.40 (127) & 5.49 (83) & $2.38(36)$ & 1512 & 5.71 & 3 \\
\hline $\begin{array}{l}\text { Surgery, such as hip } \\
\text { replacement, to help people } \\
\text { carry out everyday tasks }\end{array}$ & 4.10 & $(62)$ & 9.52 & (144) & 10.25 & (155) & 12.83 & (194) & 13.62 & (206) & 12.10 & 10.52 & (159) & 9.06 & (137) & 7.61 & (115) & $4.43(67)$ & $4.43(67)$ & $1.52(23)$ & 1512 & 5.72 & 4 \\
\hline $\begin{array}{l}\text { Health promotion/education } \\
\text { services to help people lead } \\
\text { healthy lives }\end{array}$ & 19.25 & $(291)$ & 8.13 & $(123)$ & 5.95 & $(90)$ & 7.41 & (112) & 7.34 & (111) & 7.01 (106) & 7.28 & (110) & 6.55 & (99) & 7.41 & (112) & 8.33 (126) & 7.67 (116) & 7.67 (116) & 1512 & 5.92 & 5 \\
\hline $\begin{array}{l}\text { Psychiatric services for people } \\
\text { with mental illness }\end{array}$ & 5.16 & $(78)$ & 6.22 & $(94)$ & 9.39 & (142) & 9.72 & (147) & 12.24 & $(185)$ & $11.90(180)$ & 9.99 & (151) & 11.18 & (169) & 8.86 & $(134)$ & 6.35 (96) & 5.89 (89) & 3.11 (47) & 1512 & 6.22 & 6 \\
\hline $\begin{array}{l}\text { District nursing and community } \\
\text { services/care at home }\end{array}$ & 8.47 & (128) & 7.21 & (109) & 7.80 & (118) & 8.13 & (123) & 8.93 & (135) & $10.58(160)$ & 9.79 & (148) & 8.40 & (127) & 9.26 & $(140)$ & 7.54 (114) & 8.27 (125) & $5.62(85)$ & 1512 & 6.40 & 7 \\
\hline $\begin{array}{l}\text { Long stay hospital care for } \\
\text { elderly people }\end{array}$ & 4.56 & $(69)$ & 6.68 & $(101)$ & 8.00 & (121) & 8.60 & (130) & 9.52 & $(144)$ & $10.85(164)$ & 12.50 & $(189)$ & 11.57 & $(175)$ & 11.84 & $(179)$ & 8.53 (129) & 5.49 (83) & $1.85(28)$ & 1512 & 6.44 & 8 \\
\hline $\begin{array}{l}\text { Treatment for people aged } 75 \\
\text { and over with life threatening } \\
\text { illness }\end{array}$ & 3.70 & $(56)$ & 9.52 & $(144)$ & 10.45 & $(158)$ & 9.85 & (149) & 6.94 & $(105)$ & $7.14(108)$ & 7.28 & $(110)$ & 9.13 & (138) & 8.66 & $(131)$ & $12.76(193)$ & $10.05(152)$ & $4.50(68)$ & 1512 & 6.65 & 9 \\
\hline $\begin{array}{l}\text { Special care and pain relief for } \\
\text { people who are dying }\end{array}$ & 2.31 & (35) & 3.31 & $(50)$ & 6.55 & $(99)$ & 6.28 & (95) & 9.46 & $(143)$ & 8.93 (135) & 11.71 & $(177)$ & 9.59 & (145) & 12.83 & $(194)$ & $13.36(202)$ & 9.79 (148) & 5.89 (89) & 1512 & 7.41 & 10 \\
\hline $\begin{array}{l}\text { Intensive care for premature } \\
\text { babies who weigh less than } 680 \mathrm{~g} \\
\text { with only a slight chance of } \\
\text { survival }\end{array}$ & 2.25 & $(34)$ & 4.56 & $(69)$ & 4.70 & (71) & 6.55 & (99) & 4.89 & (74) & $5.42(82)$ & 4.76 & $(72)$ & 7.01 & $(106)$ & 7.01 & $(106)$ & 9.52 (144) & $20.90(316)$ & 22.42 (339) & 1512 & 8.55 & 11 \\
\hline Treatment for infertility & 0.26 & $(4)$ & 0.79 & $(12)$ & 1.12 & (17) & 1.72 & (26) & 2.38 & $(36)$ & 3.24 (49) & 5.22 & (79) & 5.82 & (88) & 8.13 & (123) & 11.57 (175) & 16.73 (253) & $42.99(650)$ & 1512 & 10.15 & 12 \\
\hline
\end{tabular}


Table 3 - Attitudes about health priorities. Figures are percentages (numbers)

\section{Possible answers}

Strongly Disagree

Disagree

Neither Disagree or Agree

Agree

Strongly Agree

High cost technology (for example,

transplantation and kidney

machines) should be available to all

$3.90(59)$

15.94 (241)

21.76 (329)

47.16 (713)

11.24 (170)

regardless of age

If resources must be rationed, higher priority should be given to treating the young than the elderly

$7.14(108)$

$27.31(413)$

$21.56(326)$

$36.71(555)$

$7.28(110)$

The patient's quality of life should be considered in determining whether or not to use lifesaving

$15.61(236)$

12.50 (189)

47.88 (724)

21.30 (322)

treatment/technology

People who contribute to their own illness--for example, through

smoking, obesity, or excessive

$1.96(332)$

19.51 (295)

$39.15(592)$

$15.48(234)$

drinking--should have lower priority

for their health care than others

The responsibility to ration health

care spending should rest with the

doctor rather than a hospital

$18.52(280)$

$36.90(558)$

$10.85(164)$

manager, health authority, politician,

or government minister

The government should issue

guidelines to doctors about when not

to use lifesaving medical

9.39 (142)

28.57 (432)

$16.34(247)$

39.29 (594)

6.42 (97) 


\begin{tabular}{|c|c|c|c|c|c|c|c|c|c|c|c|}
\hline $\begin{array}{l}\text { Special } \\
\text { care \& pain } \\
\text { relief for } \\
\text { people who } \\
\text { are dying }\end{array}$ & $\begin{array}{c}\text { District } \\
\text { nursing \& } \\
\text { community } \\
\text { services/ } \\
\text { Care at } \\
\text { home }\end{array}$ & $\begin{array}{l}\text { Long stay } \\
\text { hospital } \\
\text { care for } \\
\text { elderly } \\
\text { people }\end{array}$ & $\begin{array}{c}\text { Treatment } \\
\text { for people } \\
\text { aged } 75+ \\
\text { with life } \\
\text { threatening } \\
\text { illness }\end{array}$ & $\begin{array}{l}\text { Treatment } \\
\text { for children } \\
\text { with life } \\
\text { threatening } \\
\text { illnesses }\end{array}$ & $\begin{array}{c}\text { Intensive } \\
\text { care for } \\
\text { premature } \\
\text { babies who } \\
\text { weigh less } \\
\text { than } 680 \mathrm{~g} \\
\text { with only a } \\
\text { clight }\end{array}$ & $\begin{array}{c}\text { Preventive } \\
\text { screening } \\
\text { services \& } \\
\text { immuni- } \\
\text { zations }\end{array}$ & $\begin{array}{c}\text { Health } \\
\text { promotion/ } \\
\text { education } \\
\text { services to } \\
\text { help people } \\
\text { lead } \\
\text { healthy }\end{array}$ & $\begin{array}{l}\text { Surgery, } \\
\text { such as hip } \\
\text { replacemen } \\
\text { t, to help } \\
\text { people } \\
\text { carry out } \\
\text { everyday }\end{array}$ & $\begin{array}{c}\text { High } \\
\text { technology } \\
\text { surgery, } \\
\text { organ } \\
\text { transplants } \\
\text { and } \\
\text { procedures }\end{array}$ & $\begin{array}{l}\text { Psychiatric } \\
\text { services } \\
\text { for people } \\
\text { with mental } \\
\text { illness }\end{array}$ & $\begin{array}{l}\text { Treatment } \\
\text { for } \\
\text { infertility }\end{array}$ \\
\hline
\end{tabular}

slight

lives tasks which treat

chance of

life

survival

threatening

\begin{tabular}{|c|c|c|c|c|c|c|c|c|c|c|c|}
\hline & & & & & & & & & conditions & & \\
\hline $\begin{array}{l}\text { Age group } \\
\text { Aged } 18-49\end{array}$ & Lower & Lower & & Higher & Higher & & & Higher & Higher & Lower & \\
\hline Aged 50-64 & Lower & Lower & Lower & & & & Higher & Higher & Higher & & \\
\hline Aged 65+ (ref) & & & & & & & & & & & \\
\hline $\begin{array}{l}\text { Education level } \\
\text { Informal education, } \\
\text { no schooling \& } \\
\text { primary }\end{array}$ & & & & & & Lower & Lower & Higher & & Lower & Higher \\
\hline $\begin{array}{l}\text { Lower \& Upper } \\
\text { secondary \& } \\
\text { Matriculation }\end{array}$ & & & & & & Lower & Lower & Higher & & & Higher \\
\hline $\begin{array}{l}\text { Tertiary (non-degree), } \\
\text { degree \& } \\
\text { postgraduate (ref) }\end{array}$ & & & & & & & & & & & \\
\hline $\begin{array}{l}\text { Econ \& Prof Status } \\
\text { Retired, } \\
\text { homemakers, } \\
\text { students or } \\
\text { Unemployed }\end{array}$ & Lower & Higher & Higher & & Higher & & Lower & & & & \\
\hline General Workers & Lower & & Higher & & Higher & & Lower & & Higher & & \\
\hline $\begin{array}{l}\text { Professionals in non- } \\
\text { HA sector }\end{array}$ & & & & & Higher & & Lower & & & & Lower \\
\hline $\begin{array}{l}\text { Professionals in } \mathrm{HA} \\
\text { (ref) }\end{array}$ & & & & & & & & & & & \\
\hline
\end{tabular}

Note: While different levels of a factor may be significantly different from the reference level, none of the above factor showed significant differences between different levels (except ref).

Age group, gender, educational level, professional status and health status were included in the model. 
Table 5 -Factors associated with agreement to statements of attitudes towards health prioritisation in HK survey (based on binary logistic regression)

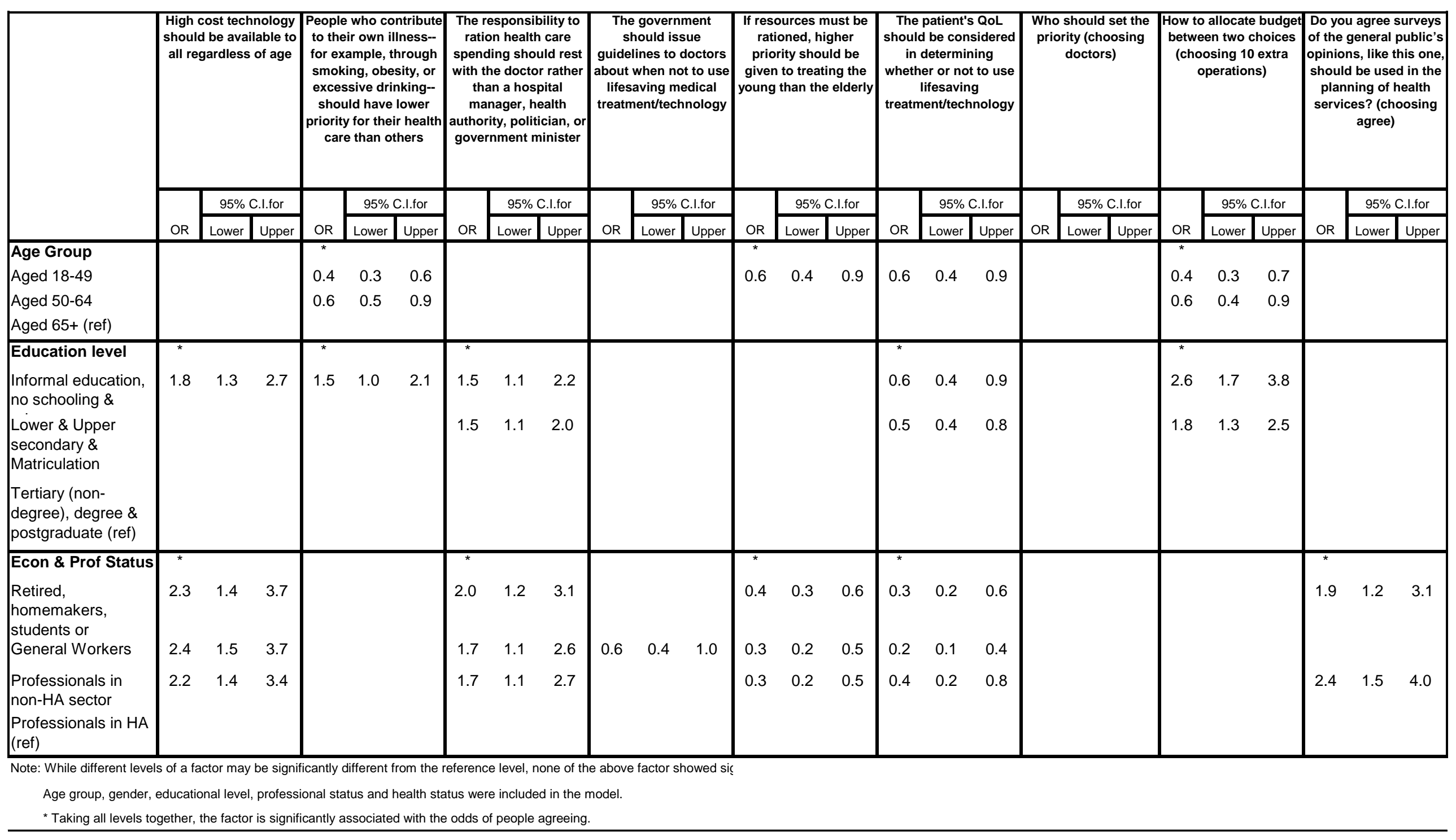


Bowling, 1996

High technology surgery, organ transplants and

procedures which treat life threatening conditions

Preventive screening services and immunisations

Surgery, such as hip replacement, to help people carry out everyday tasks

Health promotion/education services to help people lead healthy lives

Psychiatric services for people with mental illness

District nursing and community services/care at home

Long stay hospital care for elderly people

threatening illness

Special care and pain relief for people who are dying

Intensive care for premature babies who weigh less than $680 \mathrm{~g}$ with only a slight chance of survival

Treatment for infertility
1

7

HK sample (weighted)

1

2

3

4

4

8

5

6

6

5

7

8

9

2

10

9

11

11

12 
Table 7 - Comparison of Attitudes towards Health Services. Figures are percentages (numbers)

\section{Bowling, $1996 \quad$ HK sample (weighted)}

High cost technology (for example, transplantation and kidney machines) should be available to all regardless of age.

Strongly disagree

$2 \%(32)$

$11 \%(216)$

$7 \%(133)$

$55 \%(1092)$

$25 \%(505)$
$4 \%(63)$

$16 \%(246)$

$24 \%(359)$

$45 \%(685)$

$11 \%(159)$

People who contribute to their own illness--for example, through smoking, obesity, or excessive drinking--should have lower priority for their health care than others.

Strongly disagree

Disagree

Neither disagree nor agree

$10 \%(188)$

$33 \%(656)$

$15 \%(289)$

$33 \%(656)$

$9 \%(186)$
$4 \%(65)$

$24 \%(365)$

$21 \%(320)$

$36 \%(542)$

$14 \%(219)$

The responsibility to ration health care spending should rest with the doctor rather than a hospital manager, health authority, politician, or government minister.

\begin{tabular}{lcr} 
Strongly disagree & $1 \%(30)$ & $7 \%(101)$ \\
Disagree & $14 \%(271)$ & $27 \%(402)$ \\
Neither disagree nor agree & $10 \%(196)$ & $20 \%(302)$ \\
Agree & $48 \%(946)$ & $36 \%(544)$ \\
Strongly agree & $27 \%(524)$ & $11 \%(163)$ \\
\hline
\end{tabular}

The government should issue guidelines to doctors about when not to use lifesaving medical treatment/technology.

$\begin{array}{lrr}\text { Strongly disagree } & 28 \%(548) & 8 \%(124) \\ \text { Disagree } & 49 \%(962) & 28 \%(429) \\ \text { Neither disagree nor agree } & 8 \%(165) & 18 \%(265) \\ \text { Agree } & 12 \%(245) & 39 \%(592) \\ \text { Strongly agree } & 2 \%(47) & 7 \%(102)\end{array}$

If resources must be rationed, higher priority should be given to treating the young than the elderly.

Strongly disagree $\quad 5 \%(94) \quad 7 \%(100)$

Disagree

$24 \%(476) \quad 29 \%(432)$

Neither disagree nor agree $\quad 21 \%(422) \quad 23 \%(343)$

Agree $\quad 40 \%(776) \quad 36 \%(540)$

Strongly agree

10\% (203)

$6 \%(97)$

The patient's QoL should be considered in determining whether or not to use lifesaving treatment/technology.

Strongly disagree

Disagree

Neither disagree nor agree

Agree

Strongly agree

$\begin{array}{lc}2 \%(52) & 3 \%(40) \\ 12 \%(237) & 16 \%(236) \\ 12 \%(227) & 13 \%(193) \\ 51 \%(1004) & 47 \%(706) \\ 23 \%(451) & 22 \%(337)\end{array}$

